\title{
Interviews of Mongolian herders and high resolution precipitation data reveal an increase in short heavy rains and thunderstorm activity in semi-arid Mongolia
}

\author{
Clyde E. Goulden $^{1}$ (D) - Jerry Mead ${ }^{1} \cdot$ Richard Horwitz $^{1}$ • \\ Munhtuya Goulden ${ }^{1}$ - Banzragch Nandintsetseg ${ }^{2}$. \\ Sabrina McCormick ${ }^{3}$ - Bazartseren Boldgiv ${ }^{1,4}$. \\ Peter S. Petraitis ${ }^{5}$
}

Received: 25 March 2015 / Accepted: 24 January 2016/Published online: 13 February 2016

(C) The Author(s) 2016. This article is published with open access at Springerlink.com

\begin{abstract}
Increases in extreme record-breaking daily precipitation events have accompanied warming temperatures, causing increased flooding in many areas of the World, but are not well documented for arid and semi-arid regions. In semi-arid Mongolia, where warming has been over $2{ }^{\circ} \mathrm{C}$ from 1940 to 2008 , nomadic herders described their concerns over an increase in the number of hot days and a shift from multi-day gentle rains to heavy rains lasting less than one hour that damage their pastures, animals, gers and people, suggesting a transition from stratiform rains to convective storms. The brief intense rains described by the herders, are not seen in daily precipitation data typically reported by meteorological stations, and here the correlation between fine-scale rainfall readings and thunderstorm activity were used to hindcast brief heavy rains. From 2008 to 2012, an automated weather station in Dalbay Valley at Lake Hövsgöl, Mongolia, recording at 5-min intervals, detected at least 40 heavy sub-daily summer rains each lasting less than 40 min. Heavy rains in Dalbay were correlated with thunderstorm activity and were 2.5 times more likely to occur when thunderstorms were reported within the previous $24 \mathrm{~h}$ at the Hatgal meteorological station $(80 \mathrm{~km}$ to the southwest
\end{abstract}

Electronic supplementary material The online version of this article (doi:10.1007/s10584-016-1614-4) contains supplementary material, which is available to authorized users.

Clyde E. Goulden ceg64@drexel.edu

1 Academy of Natural Sciences of Drexel University, Philadelphia, PA, USA

2 Information and Research Institute of Meteorology, Hydrology and Environment, Ulaanbaatar, Mongolia

3 George Washington University, Washington, DC, USA

4 National University of Mongolia, Ulaanbaatar, Mongolia

5 University of Pennsylvania, Philadelphia, PA, USA 
of Dalbay) than when no thunderstorms were reported. Daily thunderstorm frequency, recorded at nearby meteorological stations from 1960 to 2012, has increased and thus supports herders' perceptions that the frequency of the short heavy rains have increased. Without high temporal resolution data for precipitation, such as those we report in this study, it is impossible detect shifts in summer rain types, which have many implications in theory and practice.

\section{Introduction}

The IPCC 2007 Assessment Report concluded that people in developing countries are highly vulnerable to climate change impacts and will be most affected because they are limited in how they can adapt to change. The livelihoods of rural and indigenous peoples everywhere who depend on environmental resources, plants and local wildlife including fisheries and herding of domesticated livestock will be affected by climate changes. More frequent summer heat waves and intense summer storms will be more variable in occurrence and are predicted to alter species' phenology and ecosystem services (Knapp et al. 2008; Mooney et al. 2009) and for indigenous peoples (Crate 2011a). Thermal conditions are very important and a great deal of information has been accumulated on trends of maximum daily and extreme temperatures (IPCC 2007). Variability of precipitation, particularly sub-daily rains have yet to be studied in detail because precipitation data are commonly reported as daily values in many countries while these storms seldom last more than one to two hours (Trenberth et al. 2003) more precise information is needed to monitor and model precipitation changes.

The phenology of many plant and animal species depend on seasonal patterns of precipitation, the timing of spring or summer rains and melt of winter ice and snow packs (Crate 2012). Soil moisture is essential for plant growth. But short intense rains often runoff quickly and cause flooding (Rahmani et al. 2015) and along with increased evapotranspiration can result in decreased soil moisture (Knapp et al. 2008). Reduced soil moisture can affect agricultural crop production for rural and indigenous peoples (Bates et al. 2008; Lesk et al. 2016). For adaptation to variable water resources to be effective it is critical that changes in precipitation patterns be understood.

Recent research has focused on meteorological data extremes, often ignoring the evidence of human experiences and "exposure" in vulnerable regions (Simelton et al. 2013). Few studies have examined whether local populations have the capacity to adapt to the breadth of changes, an area that anthropologists can play a major role (Crate 2011b). In northern Mongolia's semi-arid steppe, nomadic herders depend on seasonal climate patterns, summer rains and winter snows when moving their animals to different habitats with fresh pastures. They must move animals to seasonal pastures with dependable water resources, lowlands receiving the summer rains of rivers and streams or small ponds, and in the winter to mountain top ridges that are warmer than valleys and with snow as a primary water source.

To improve understanding of human exposure to climate change impacts, we combined interviews with nomadic herders (conducted between 2009 and 2012) with both historical daily (1961 to 2011) as well as high precision meteorological data from 2008 to 2012 to corroborate the herder's assessment of the impacts of their changing environment. In the first part of this manuscript we review changes in global precipitation patterns as a context for summer rain changes in Mongolia described by nomadic herders. We compare the herder descriptions with sub-daily intense storm events identified in precipitation data collected over a 5 year period by an automated meteorological station recording at 5 min intervals. These short intense storms occur almost weekly and can cause serious environmental damage, but are not 
evident in "daily" precipitation data. Following this recognition, we added a third objective to demonstrate why it is critical to improve precipitation monitoring programs. The questions posed in this paper are the following: 1) Are the intense rains described by herders detected in meteorological data? 2) Are they comparable to "extreme" events described elsewhere? 3) Why are the reported impacts of the intense storms so damaging to herder livelihoods?

\subsection{Intensity of precipitation}

The American Meteorological Society has characterized precipitation as "light" (a trace to $2.5 \mathrm{~mm} \mathrm{hr}^{-1}$ ), "moderate" (2.6 to $7.6 \mathrm{~mm} \mathrm{hr}^{-1}$ ), and "heavy" (over $7.6 \mathrm{~mm} \mathrm{hr}^{-1}$ ) (Glickman et al. 2000). Similar classifications are used elsewhere in the world including in Mongolia where rains (boroo) are described as Shivree boroo (warm rains with small droplets and little wind; precipitation rates are $\leq 2.5 \mathrm{~mm} \mathrm{hr}^{-1}$ and continue for up to 3-4 h), Namira a boroo (gentle rains on partly cloudy days and often associated with rainbows), Zuser boroo (constant rains that last 2-3 days of low to medium intensity with small droplets and rates of $\leq 2.5 \mathrm{~mm} \mathrm{hr}^{-1}$ ), and Aadar boroo. Aadar rains are intense short, patchy rains with large drops, often with hail, associated with thunder, lightning, and precipitation rates greater than $7.6 \mathrm{~mm} \mathrm{hr}^{-1}$ (NAMHEM 2008).

\subsubsection{Heavy precipitation}

As global temperatures have warmed, total annual precipitation has increased and become more variable (Dore 2005; Alexander et al. 2006; IPCC 2007; Westra et al. 2014). Annual precipitation is expected to increase with the water-holding capacity of a warmer atmosphere, an approximate $7 \%$ more water vapor per $1{ }^{\circ} \mathrm{C}$ warming as described by the ClausiusClapeyron relation (C-C relation, IPCC 2007; Jones et al. 2010). Westra et al. (2013) analyzed long-term records and confirmed that "global annual maximum daily rainfall" was increasing at a rate consistent with the C-C relation. Lehmann et al. (2015) found during the last decade an increase in "record breaking daily rainfall events" globally best fit a model based on the C$\mathrm{C}$ relation. Lenderink and van Meijgaard (2010) found intense hourly precipitation events to equal and even double expectations predicted by the $\mathrm{C}-\mathrm{C}$ relation increase for temperatures between $12{ }^{\circ} \mathrm{C}$ and $22{ }^{\circ} \mathrm{C}$. These and subsequent studies demonstrate a so-called "super" C-C scaling of rainfall intensity that can be very damaging to ecosystems and to people (Easterling et al. 2000; Westra et al. 2014; Feng et al. 2015).

The increase of heavy rains is consistent with a transition from stratiform rains to short intense convective "storms" (Trenberth et al. 2003; Haerter and Berg 2009; Berg et al. 2013; Rulfova and Kysely 2013, 2014). A shift in cloud structure from decreased low-lying stratiform clouds to increased higher-level cumulus clouds has been documented for the Former Soviet Union, including the border area with northern Mongolia (Sun and Groisman 2000).

\subsubsection{Extreme precipitation}

Record rainfall amounts are becoming common in newspaper headlines in many places around the world. In Beijing, China July 24, 2012, between 200 and $400 \mathrm{~mm}$ of rain fell during an overnight storm, flooding streets and buildings (http://earthobservatory.nasa.gov/ NaturalHazards/view.php?id=78626). Similar record breaking heavy rainfall occurred in Islip, NY on August 13, 2014, with up to $344 \mathrm{~mm}$ falling over a $24 \mathrm{~h}$ period, and an intense burst of $27 \mathrm{~mm}$ in nine minutes, resulting in serious landscape erosion and serious flood 
damage to highways and local communities (http://www.weather.gov/okx/HistoricFlooding 081314). Though presently rare at a specific geographic location, having occurred only once at Islip, NY for example, extreme record breaking heavy storms are becoming more common globally and are dependent upon local weather conditions (Lehmann et al. 2015) with resultant serious property damage and loss of life. This does not necessarily mean that all places are experiencing higher rainfall; many areas of the world are having unprecedented droughts due to climate change. Increased annual precipitation is a global mean which translates to many places having increased precipitation, some having the same and some less.

A great deal of emphasis has been placed on the loss of human lives and economic costs of property of "extreme" climate events. Extreme climate events are often defined as recordbreaking events that exceed the $95^{\text {th }}$ or $99^{\text {th }}$ percentiles in frequency distributions of "daily" or $24 \mathrm{~h}$ total precipitation for a region (Alexander et al. 2006). They have been more precisely defined as a "climate variable above (or below) a threshold value near the upper or lower ends of the range of observed values of the variable." (p. 3, Field et al. IPCC 2012). Extreme precipitation events are documented to cause serious soil erosion (Feng et al. 2015).

Analysis of "daily" precipitation data (e.g. GHCN-Daily=total precipitation during a $24 \mathrm{~h}$ period) indicates that extreme events have increased in most areas of the World (Groisman et al. 2005; Alexander et al. 2006; Westra et al. 2013), often with record breaking levels of precipitation (Lehmann et al. 2015), documenting the global character of climate change.

\subsubsection{Daily vs. sub-daily precipitation}

Large scale rainfall events $\left(\geq 10 \mathrm{~mm}^{\text {day }}{ }^{-1}\right.$ ) are easily detected in daily measurements of precipitation. Sub-daily events seldom last a full hour and may be followed by $2-3 \mathrm{~h}$ of light rains, making it difficult to determine their importance. Short rainfall events $\left(<5 \mathrm{~mm}\right.$ day $\left.^{-1}\right)$ in semi-arid regions can compose most of the annual rainfall total, and their moisture is effectively utilized by the local dominant plant species and is critical for microbial nutrient cycles (Sala and Lauenroth 1982). The intensity of sub-daily rains undetected in daily rainfall data are also increasing. Jones et al. (2010) described "extreme sub-daily precipitation" events from Australia that "are consistent with the $\mathrm{C}-\mathrm{C}$ relationship for surface temperatures up to between $20^{\circ} \mathrm{C}$ and $26^{\circ} \mathrm{C}$ and for precipitation durations up to $30 \mathrm{~min}$ ". These short intense rainfall events appear to form one end of a spectrum of heavy rains extending to "extreme" events (e.g. Islip, NY), their length and intensity depending on regional conditions and the amount of atmospheric moisture available (Moseley et al. 2013; Westra et al. 2014). They alter hydrological cycles, terrestrial plant composition (Spence et al. 2015), plant growth (HeislerWhite et al. 2008), ecosystem structure, and disrupt ecosystem services (Knapp et al. 2008; Mooney et al. 2009).

\section{Herder interviews}

Many rural and indigenous peoples depend directly on their environment for food and other resources, using an intimate expert knowledge of their local environment that provides insight into the impacts of environmental change (Berkes 2008; Crate 2008, 2011a, b, 2012; Cuerrier et al. 2015). Their keen adaptation to an already extreme environment is a critical skill in the context of how climate change is increasing that extreme and the unpredictability (FernandezGimenez 1993; Parlee et al. 2006; Simelton et al. 2013). Local communities' recent efforts to 
monitor their environment, using environmental indicators and communication with relatives and others within their group, improves the accuracy of their perception of unprecedented environmental change (Parlee et al. 2005).

Nomadic pastoralists of Mongolia practice a way of life of their ancestors that dates back at least 3000 years (Barfield 1989). Knowledge is both passed on from generation to generation and also innovated by the new generations as conditions change. Almost one third of Mongolia's present population are nomadic herders that tend mixed herds of sheep, cashmere goats, horses, and cows or yaks in the north and camels in the south. They follow many traditions from the past, including the traditional ger (a collapsible, portable, sturdy dome dwelling, known in Russia as a yurt), to care of animals and timing of seasonal movements to avoid overgrazing pastures. Timing is critical for their movements and knowing when to shear the sheep and comb the goats, or when, where and how much winter hay (hadlan) to collect. Timing of seasons are altered by climate change and herders must adjust their movements. They are directly exposed to and concerned about the weather and this is summed up in a common saying, "Any change in the weather is bad!"

Herders depend on local knowledge to determine where and when to move their livestock (Fernandez-Gimenez 2000) and how much hay to collect. Mongolia's climate is characterized by large inter-annual climate variability of years with good rainfall interspersed with long drought periods (Nandintsetseg and Shinoda 2013a, b). Summer precipitation is particularly important for the people of the semi-arid steppe because it sustains the growth of the grass while animals are feeding. If the summer rains begin late in June, residual grasses from prior years are quickly overgrazed. The main objective of herders for the summer grazing is to make sure their animals are "fat and strong" to survive the harsh winter. Droughts disrupt movements and if long lasting, herds must stay near rivers, wells or springs where grasses are heavily grazed. If a summer drought is followed by a cold or snowy winter and little fodder (hadlan), many animals will be lost during a dzud (very cold winter where animals cannot access food; Fernandez-Gimenez et al. 2012).

Climate change is having an impact on the steppe of Mongolia where warming has been estimated to be $>2{ }^{\circ} \mathrm{C}$ from 1940 to 2008 (Dagvadorj et al. 2009; Nandintsetseg et al. 2007). Interviews of Mongolian nomadic herders' perceptions of environmental changes suggest they are very concerned over the increase in summer hot days "that burns the grasses", decreased multi-day gentle rains (shivree or zuser boroo) and increased intense cold thunderstorms (aadar boroo). These heavy rains damage pastures, injure and kill animals, and are a threat to individuals tending animals. Similar description of the rain changes have been reported from herder interviews in central Mongolia by Marin (2010) and in the Gobi (Jigjsuren et al. 2015).

\subsection{Site description and herder movements}

Northern Mongolia forms a transition from the Siberian taiga forest in the north and the semiarid steppe and desert to the south, with an average annual precipitation of $230 \mathrm{~mm}$ (Batjargal 2007). The taiga forest of Mongolia primarily consists of larch (Larix sibirica), and the steppe is a short-grass prairie of Potentilla acaulis and sedges as co-dominants (Spence et al. 2015; Ariuntsetseg et al. 2013). Herds are typically moved seasonally or more often in response to poor pasture conditions from overgrazing, drought and other extreme weather conditions (Humphrey and Sneath 1999). Herders use their knowledge of the seasonal availability of water, snow, and locations of ungrazed pastures to determine where and when to move their herds among traditional seasonal grazing areas. Knowledge from their parents and elders is 
critical to their survival. Summer pastures are in lowland areas near water sources and winter pastures are in upland or mountainous areas where animals depend on snow and ice for water. Herders cut grass for hay to feed young and pregnant cattle while most of the animals feed on residual summer plants. Very cold winters with heavy snow and ice, termed a $d z u d$, can kill many animals (Batjargal 2007; Fernandez-Gimenez et al. 2012); herder families have lost entire herds due to dzuds and must move to cities to find jobs.

\section{Materials and methods}

\subsection{Interviews}

We developed an open-ended questionnaire (Questionnaire 1 in Supplementary Material) with general questions that allowed herders to respond with their perceptions of recent environmental changes. Herders try to place their ger near a country road; we simply drove along the road and stopped randomly at gers, and asked the occupant if we could talk with them and ask about their perceptions of environmental changes and record their responses. All families were willing to speak with us. We interviewed 32 families from the Lake Hövsgöl ILTER site (Fig. 1 northwest of Ulaanbaatar) in 2009 and 64 families from Hentii Aimag (Batshereet, Bayan Adrag, Bindern, and Ondorkhan, east of Ulaanbaatar) in 2010 (Fig. 1). Interviews typically lasted one to two hours and were recorded. We never commented on what other herders had said and did not interrupt the interviewee during their comments though we might ask for clarification of a statement. The complete interview was in Mongolian language (MNG). We

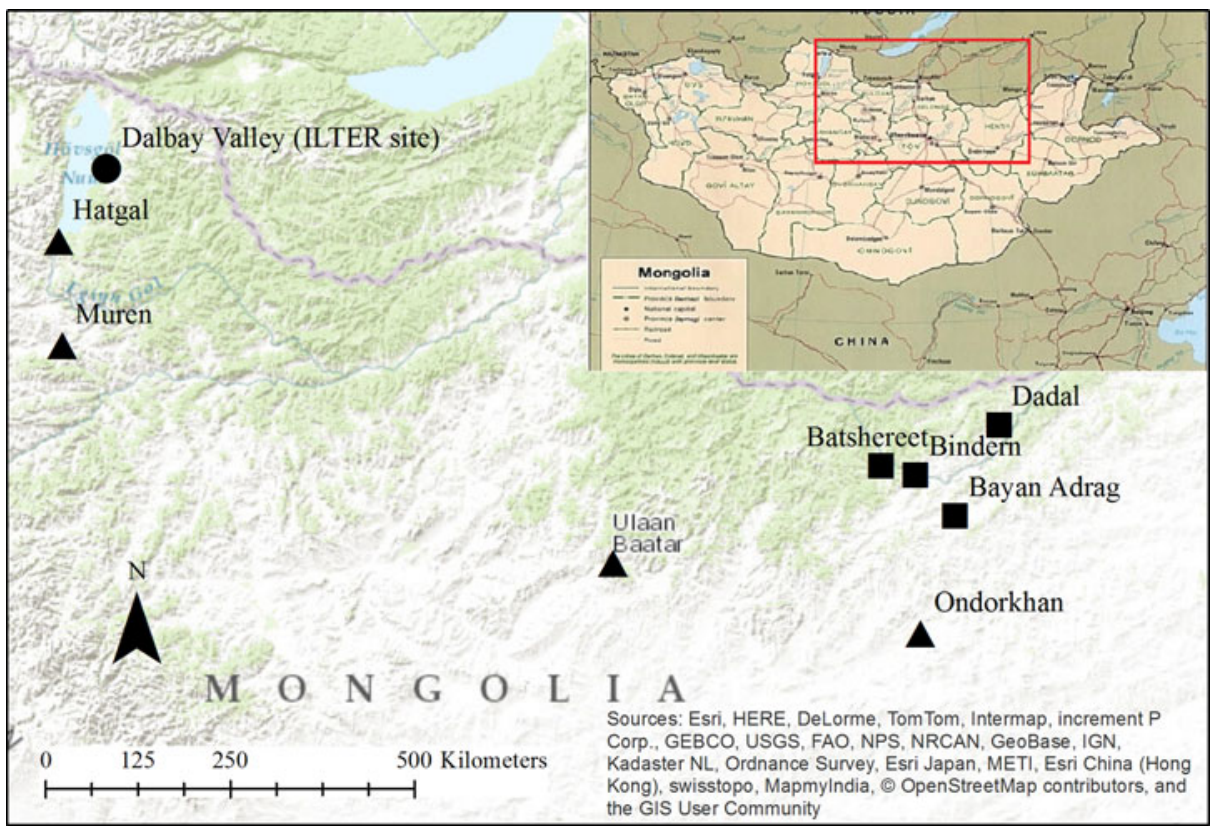

Fig. 1 Tiff Research locations in northern Mongolia with inset of Mongolia. Black triangle=location of meteorological data monitoring sites; Black circle=location of five-minute monitoring meteorological station and of region of interviewed Hövsgöl herders; Black squares = locations of Hentii herder interview areas 
never used the terms "climate change" or "global warming" in the initial interviews to describe what we were asking except at the end of an interview we might ask a herder about climate change or global warming. After translation, the responses were formatted for QSR's NVivo 9 and categorized using the query function. The results were grouped and organized into alternative responses for a subject or question. Response percentages were estimated from this grouping.

In order to learn more about precipitation changes we returned to the same areas in 20112012 with a multiple-choice questionnaire to ask many of the same herders to rank their perceptions of the present frequency of each rain type (zuser, aadar, shivree, namiraa, or do not know) now and relative to when they were children. Their responses were scaled for each rain as 1-abundant, 2-common, 3-seldom and 4-rare for each rain (Questionnaire 2 in Supplementary Material). We were unable to find several of the families previously interviewed and if new herders had moved into the area we interviewed these herders. We interviewed a total of 78 herders (28 from Hövsgöl in 2011 and 50 from Hentii in 2012). The rankings were tested with a sign test based on each individual's paired ranking of present and past rain type.

\subsection{Daily meteorological data}

The use of precipitation "extremes" allows a global comparison of daily maximum values of precipitation as briefly described by Alexander et al. (2006). To encourage analysis of longterm trends for climate "extremes", the World Meteorological Organization (WMO) developed a software package (Climdex) to calculate a series of indices from long-term weather data sets [http://www.climdex.org/indices.html20062011]. Weather data from Mongolia's Institute of Hydrology, Meteorology and Environment were used for analysis of the indices. Daily data were obtained from near Lake Hövsgöl at Hatgal (N50²7.829'; E111¹0.421'; 1961 to 2011), from Muren (49³8'74"; 1960 to 2011), the capital of Hövsgöl Aimag, and from Ondorkhaan (N47¹9.587'; E110³9.813'; 1970 to 2005) in Hentii Aimag (Fig. 1). We used the "R" version software of WMOs Climdex to calculate trends for the temperature and precipitation indices. Climdex analysis requires long-term records of temperature and rainfall that initially undergo a rigorous $\mathrm{QA} / \mathrm{QC}$ review for outliers and missing data. In addition to temperature trends, the precipitation indices included testing for historical trends in "R10", the annual number of days when precipitation was $\geq 10 \mathrm{~mm} /$ day, "R95pTOT", a significant increase or decrease with time in the frequency of precipitation of the $95^{\text {th }}$ percentile of total rains or "R99pTOT", the $99^{\text {th }}$ percentile, and finally, "Rx1day" representing a change in annual total precipitation of monthly maximum 1-day precipitation.

\subsection{Sub-daily meteorological data}

To estimate absolute precipitation intensities for sub-daily time periods we used data from an automated meteorological station (Hobo Model U30-NRC), monitoring solar radiation, temperature, precipitation, relative humidity, wind speed and direction, set up in Dalbay Valley (Fig. 1), a tributary valley entering Lake Hövsgöl along its northeastern shore and previously designated as an International Long-Term Ecological Research (ILTER) study location. During the summer months from mid-June to late August of 2008 to 2012 the station was set to record at five-minute intervals. A calibrated tipping bucket rain gauge (RG3-m sensor) was mounted at a two-meter height. The resolution of the tipping bucket rain gauge is $0.2 \mathrm{~mm} \mathrm{tip}^{-1}$. 
Calibration indicated the gauge was consistently accurate. Only summer data were used for this study so that problems with snow and sleet should not be a serious problem. Corrections for wind effects were not added to the tipping bucket collector.

Our threshold for aadar rains was slightly more conservative than the standard definition used in Mongolia. To define aadar rains, Mongolia's National Agency for Meteorology, Hydrology, and Environment Monitoring (NAMHEM 2008) used the same definition of "heavy" rains, $7.6 \mathrm{~mm} \mathrm{hr}^{-1}$ published in the Glossary of the American Meteorological Society (p. 624, Glickman et al. 2000). We used $\geq 0.8 \mathrm{~mm} /$ five minutes because the tipping bucket gauge had been set for five rather than six minute intervals. In this paper we will use the terms "heavy" or "aadar" rains interchangeably so that herder statements remain consistent.

The number of days with thunderstorms at Mongolian weather stations was obtained from the NOAA data sets for Hatgal, Muren, Ondorkhaan, and Ulaanbaatar designated as "Thunderstorms with or without precipitation"; [https://gis.ncdc.noaa.gov/map/viewer/\#app= cdo\&cfg $=$ cdo\&theme $=$ precip\&layers $=000111]$. Thunderstorms were averaged over sequential 5-year summer periods at each site and were analyzed by linear regression for data from 1961 to 2012. A day was counted as having a thunderstorm if a storm occurred in at least one of the observation periods during that day; thunderstorms were tallied as occurring with or without rain. Years in which $>35 \%$ of the summer days were missing observations and 5-year periods with less than 4 years of data available were dropped from the analysis. We matched aadar rains in Dalbay with the number of days with reported thunderstorms in Hatgal, the nearest meteorological station with a good data set. Storms often move across the lake and up the lake during the summer and from the northwest in the winter. Based on wind speeds measured by the Dalbay meteorological station, we assumed a thunderstorm recorded in Hatgal would require an average of 8-12 $\mathrm{h}$ to arrive at Dalbay. Thus aadar rains occurring before $1200 \mathrm{~h}$ were linked to thunderstorms on the previous day. In order to account for travel time of 8 to $12 \mathrm{~h}$ from Hatgal to Dalbay, days at Dalbay were treated as running from 1200 to $1159 \mathrm{~h}$ the next day. The majority of storms occurred between 1600 and $0400 \mathrm{~h}$. Statistica software was used to perform simple linear regressions.

\section{Results}

\subsection{Interviews}

Most herders from the 96 families interviewed in 2009-2010 recognized that winters are now milder and summers have a succession of hot days followed by cold rainy days. During openended interviews, $98 \%$ of herders said that rains had changed, $89 \%$ said the rains were heavy or more intense, $82 \%$ said the rains were colder, and $61 \%$ said the rains were shorter.

During the 2011-2012 interviews, we asked herders specific questions about the rains and past changes. Aadar rains were perceived as more common now than in the past $(P<0.001)$. Shivree, zuser and namiraa rains were seen as less common $(P<0.001)$.

Despite being short rains, herders interviewed in 2011-2012 claimed the aadar rains were very damaging to their pastures, their animals and their families while tending herds:

"The aadar rain in September [2011] eroded the road; very intense, very dangerous. [The] ger was flooded, mattresses were floating. The pasture was covered with running water." (HP004, 2012; HP number identifies an individual herder). 
"During a previous year [2011] we had [an] extremely intense hard rain, [it] killed many animals. It happened on 20 June." (HPO77, 2012).

"We had [an] extremely hard, windy rain that knocked down many trees, our fodder was blown up into the air, and we lost half of the fodder. Our ger was damaged and knocked down in 2010." "Aadar rains run-off eroding the soil, knocking down the fences, and [it] could knock down the ger." "Aadar is brief so there is no benefit in terms of wetting the soil." (HP024, 2012).

"Last year at the end of July, I experienced [an] aadar boroo. It was very intense and heavy. The wind was extremely strong [and] gusty; large trees were falling; white birches were broken in half. It was dangerously intense." (HP023, 2012).

"Last year, we had [a] very intense heavy rain, it happened on 20 July. Within [a] few minutes, [the] whole area was covered with floodwaters, if it had rained a few more minutes, we could have been wiped out. It was very intense." (HP019, 2012)

"Aadar boroo, thunder and lightning, intense, heavy rain within short period rain."

"Aadar boroo was experienced frequently, especially previous summer. I am always scared of that kind of rain." (HP092, 2012).

Intense aadar rains are now of profound concern to the herders. One herder stated, "When we were kids we never heard of animals dying because of rain, but now animals freeze to death during the cold rain." (HP004, 2012). Herders fear for their children if caught in an aadar rain while playing or watching the animals.

\subsection{Meteorology}

None of the Climdex daily precipitation indices indicating significant trends in extreme events (e.g., R10, R95pTOT, R99pTOT, and Rx1day) were significant for Hatgal, Ondorkhan, or Muren except for a negative slope for R99pTOT $(P<0.05)$.

Analysis of the 5-min precipitation data from Dalbay Valley revealed 40 short heavy rain events $(\geq 0.8 \mathrm{~mm} / 5$ minutes) during the 2008 to 2012 summer rainy seasons (late June to late August, Fig. 2). The most intense rainfall during a 5-min interval was $3 \mathrm{~mm}$ on July 12, 2010. The average continuous duration of events ranged from $8 \mathrm{~min}$ in 2009 to $21 \mathrm{~min}$ in 2012. The largest single event was $8.8 \mathrm{~mm}$ during a 35-min period in 2012. These rains were remarkably consistent with the herders' descriptions of intense and cold, short rains from the initial open-ended interviews.

We examined the link between aadar events in Dalbay Valley and the timing of thunderstorms reported at the Hatgal meteorological station to examine the assertions of herders that aadar rains are often associated with thunder and lightning. Lake Hövsgöl lies in a graben depression with its axis from south to north and surrounded by mountain ridges 1000 to $2000 \mathrm{~m}$ above the lake. Winds are not limited to the Siberian northerlies typical of this region of East Asia but vary from night to day (Kozhova et al. 1989). We compared the timing of the Dalbay aadar storms with Hatgal thunderstorms and found that $73 \%$ of aadar rains coincided with thunderstorms reported the day before, the same day, or the day after. When we compared only the Hatgal thunderstorms on the day before a Dalbay aadar rain event between 2008 and 2012, $60 \%$ of Dalbay aadar rains occurred within a $12 \mathrm{~h}$ period following reports of thunderstorms at Hatgal (Chi-square test of independence, $P<0.02$ ). Only a 
Fig. 2 Tiff The occurrence of short intense (aadar) rains at Dalbay Valley, Lake Hövsgöl, Mongolia, 2008 to 2012. Rate of precipitation during rainfall events was measured at 5 min intervals. The horizontal lines equal $0.8 \mathrm{~mm} /$ five minutes (i.e., $9.6 \mathrm{~mm} \mathrm{hr}^{-1}$ ), the threshold for heavy (aadar) rains used in this manuscript. The number above each aadar event is the total duration of each storm event in minutes at the resolution of $5 \mathrm{~min}$. Vertical bars without numbers were smaller rain events or those lasting $<5 \mathrm{~min}$

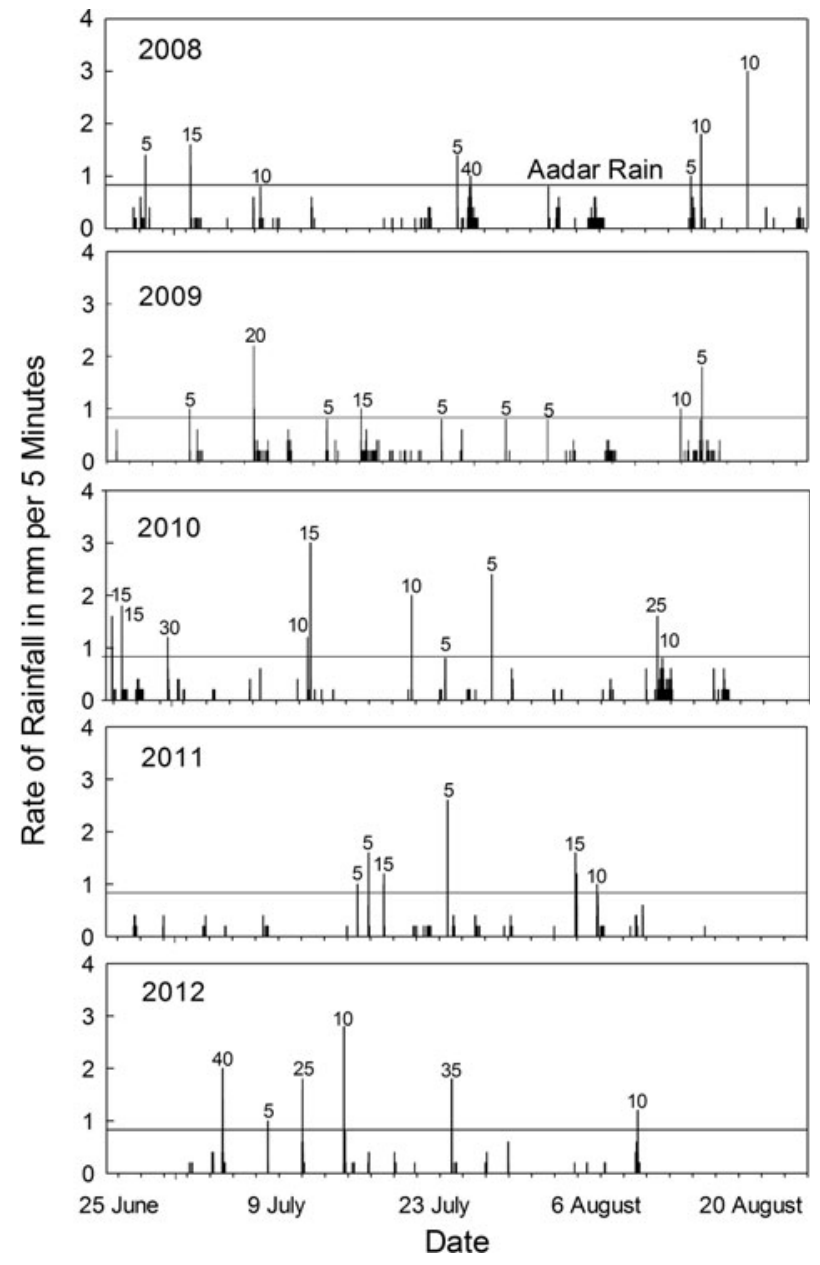

$36 \%$ co-occurrence would be predicted assuming an independence of association between Hatgal thunderstorms and Dalbay aadar rains. The occurrence of a thunderstorm at Hatgal is 2.5 times more likely to predict an aadar rain than the lack of a thunderstorm (i.e., relative risk $=2.5,95 \%$ confidence limits: 1.4-4.4).

To hind cast the frequency of aadar rains, we examined long-term thunderstorm records for nearby meteorological stations at Hatgal, Muren, Ondorkhaan, and Ulaanbaatar (Fig. 3). The trend is significant for Ondorkhaan $\left(0.28\right.$ additional storms $\mathrm{yr}^{-1}$; $P<0.01)$, Ulaanbaatar $\left(0.22\right.$ additional storms $\left.\mathrm{yr}^{-1} ; P<0.01\right)$ and for Muren $(0.22$ storms $\left.\mathrm{yr}^{-1}, P=0.01\right)$ but not significant for Hatgal $(P>0.05)$. While, Muren, Ondorkhaan and Ulaanbaatar data are similar with little difference in the slope of the regressions, the Hatgal data has considerable unexplained variability in thunderstorm activity.

Analysis of the ability to detect the short storms in "daily" precipitation data (calculated by summing the five minute readings for each day) determined that their occurrence is undetectable following a two- to four-hour period of continued light rains (see supplementary material). 


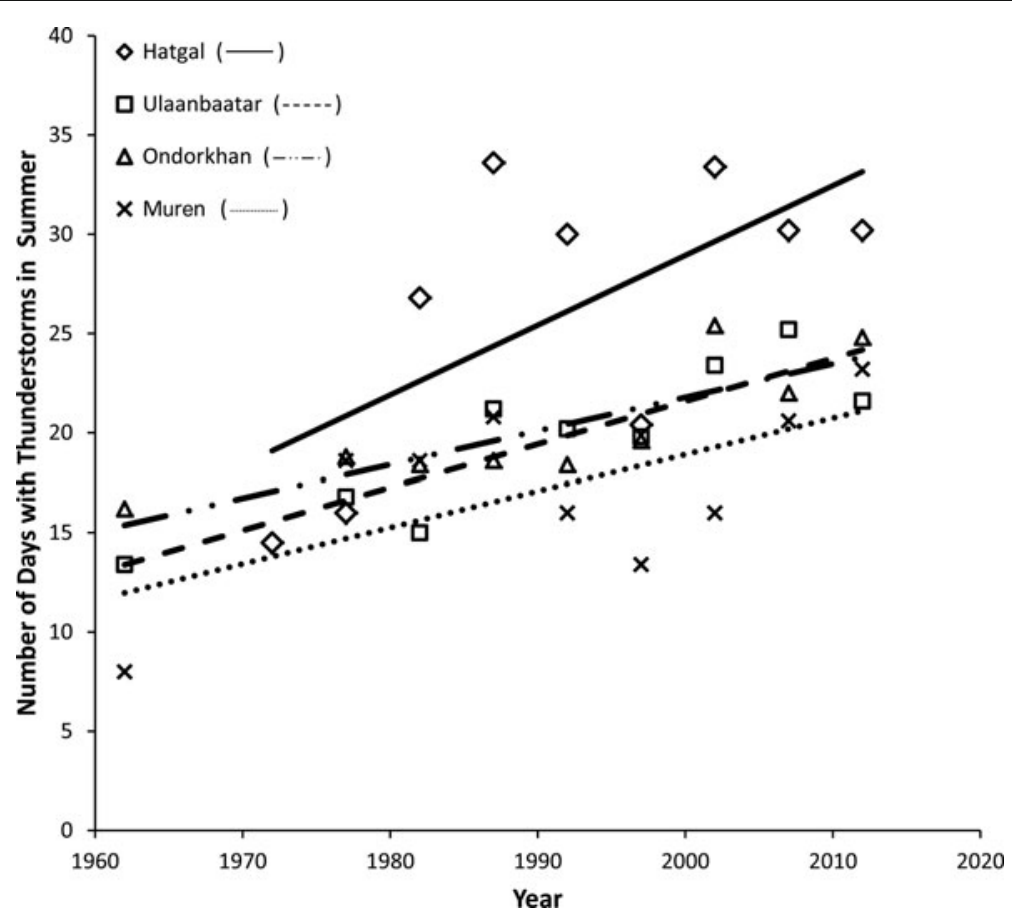

Fig. 3 Tiff Trends in northern Mongolian summer thunderstorms from 1960 to 2012 based on NOAA past weather observed database for each location from table of "Thunderstorm(s) with or without precipitation". Thunderstorms were averaged for each 5 year period that met the restriction described in the Methods section. Slopes are significant for Ulaanbaatar (slope $=0.22, R^{2}=0.83, P<0.01$ ), and Ondorkhaan (slope $=0.28, R^{2}=0.89, P<0.01$ ) and Muren (equals Moron slope $=0.22, R^{2}=0.79, P<0.01$ ). Slope is not significant for Hatgal (slope $=0.34, R^{2}=0.52, P>0.05$ )

\section{Summary and discussion}

Interviews with Mongolian nomadic herders from northern Mongolia suggested that summer rains have changed from several hours of light rains to very intense short rains that are very damaging to their property and to themselves while watching their animals. Analysis of summer precipitation data collected at 5-minute intervals by an automatic weather monitoring station in Dalbay Valley, Lake Hövsgöl, Mongolia revealed forty short heavy rains during a 5-year period from 2008 to 2012 (Fig. 2). These rains lasted no more than 30 to $40 \mathrm{~min}$, were very intense ranging from $0.8 \mathrm{ml} / 5$ minutes to $3 \mathrm{ml} / 5$ minutes, and were not apparent in the daily rain data.

These heavy rains occurred within a day of thunderstorm activity reported at the Hatgal weather station, $80 \mathrm{kms}$ south of Dalbay. An increase in thunderstorm activity since the early 1960s in northern Mongolia (Fig. 3) supports herder perceptions of an increasing trend of the short heavy rains.

This conclusion is based on analysis of rains during the summer rainy season, June to August, when 75 to $80 \%$ of rainfall occurs in northern Mongolia. These heavy rains, often associated with strong winds, and occasionally with hail, damages gers, fodder fields and increases erosion in pastures. Herders' describe storms that kill animals and injure herders if caught outside without proper clothing during an aadar rainstorm. Similar rain changes have been reported in herder interviews from south central Mongolia and in the Gobi of southern Mongolia (Marin 2010; Jigjsuren et al. 2015). 
Herder perceptions of the heavy rains, cold and intense, fits the description of convective storms and are consistent with a transition from mild, longer lasting stratiform rains to short intense convective "storms" (Trenberth et al. 2003; Haerter and Berg 2009; Berg et al. 2013; Rulfova and Kysely 2013, 2014). We found no increase in the frequency of rain days per year, nor an increase in timing between summer rain days as reported in some arid regions (Petrie et al. 2014).

Little is known of the consequences of the short intense rains impact on plant growth and soil moisture in semi-arid regions. Sala and Lauenroth (1982) concluded that frequent small precipitation events are important in providing moisture to microorganisms that occur in the surface soil (crust) and are critical to nutrient cycling in semiarid grasslands. In many semi-arid regions there is a soil crust composed of lichens with cyanobacteria that fix nitrogen. Will frequent small heavy rains still be as important if small events consist of heavy rains, particularly when the rains quickly flows off to nearby streams causing serious flooding and erosion problems and may disrupt the soil crust?

The frequency of sub-daily heavy rains is not well described (Lenderink and van Meijgaard 2008; Jones et al. 2010; Westra et al. 2014). Why are these aadar rains causing so much damage to the herders of Mongolia? Flooding may be part of the problem, and increased flooding associated with climate change has been described for the central U.S. (Mallakpour and Villarini 2015). Descriptions of intense rains in the long records of rains described by Lenderink and Meijgaard (2008, 2010), Jones et al. (2010), and Berg et al. (2013) all conclude that short rains (one hour to thirty minutes or less) can be more intense than daily rains; as much as two times the C-C relation. Their destructive character, described by the Mongolian herders, may result from an intensity exceeding the $\mathrm{C}-\mathrm{C}$ rate when associated with convective-type rains (Berg et al. 2013), but we have not documented the intensity relative to the $\mathrm{C}-\mathrm{C}$ relation for Mongolia.

The potential impacts of future rains for arid and semi-arid regions have been described by Knapp et al. (2008) and Thomey et al. (2011) and would lead to altered soil moisture conditions, variation in plant net primary production, and stream hydrology. Any change in the pattern of precipitation events would have a negative impact on the stability of terrestrial plant communities in semi-arid areas but experimental manipulation of precipitation intensities indicates that a few extreme events may actually increase soil moisture and result in increased primary productivity (Thomey et al. 2011). Whether or not the short intense rains described in the present paper have a positive impact on soil moisture and plant growth requires additional experimental studies under different soil condition. The only present studies to evaluate longterm plant biomass trends in Mongolia (Nandintsetseg and Shinoda 2013b, 2014) describe a trend of lower soil moisture, drying soils and decreased aboveground plant biomass for most of Mongolia after 1995. This coincided with a drought, but are also consistent with herder claims that the short intense rains failed to moisten the soil.

The short Mongolian heavy rains appear to represent the lower end of a spectrum of intense rains (Westra et al. 2014), a spectrum that extends to longer-lasting very damaging rains of the type that hit Islip, New York, in 2014. The review by Westra et al. (2014) suggests that similar rains will continue and become more widespread globally, their magnitude dependent upon the amount of atmospheric water available to "feed" each storm, thus areas near the ocean may experience longer and more damaging events.

Focus primarily on "extreme" daily events, effective for understanding global rainfall changes, would have missed the short storms that appear to be more common and with their own destructive character in semi-arid regions. 
Mongolian herders are very concerned over the increase and impact of intense rains that damage pastures, leave the soil dry and destroy winter hay fields. They want to know when an intense rain may occur so they can protect themselves and their family members when tending their herds.

In response to an interview question of how each herder will adapt to future weather changes to protect their livelihoods, $51 \%$ said they would need to collect more winter hay, $19 \%$ will move more often, $30 \%$ will adopt "sustainable practices" by reducing herd sizes by eliminating weak animals and some or all cashmere goats because of the damage goats do in the pastures. Collecting more winter hay depends on how well the grasses grow, and moving more often to summer pastures depends on pasture availability and requires more movements by each family. One third of the herders also stated that they were not prepared. "I am not well prepared. What can you do with weather? It's beyond our control.” (HP004).

Acknowledgments The PIRE-Mongolia Project was funded by a U.S. National Science Foundation grant (OISE 0729786) and herder interviews were also partially funded by the Cottswood Foundation and the Trust for Mutual Understanding. We thank Brent Helliker for establishing the meteorological station at Dalbay and other US and Mongolian researchers who maintained the station throughout the summer months. A local herder, Hurelchuluun, and his family maintained the station during the winter months. Thanks to the Lake Hövsgöl National Park Director and rangers for allowing us to work in the park. The National University of Mongolia maintains the ILTER research site in Dalbay Valley, and provided transportation for travel to the research site and for visits to herder families for interviews. We thank Roger Thomas of the Patrick Center, Academy of Natural Sciences of Drexel University for assistance in preparing the figures, and Elizabeth K Finch for help in editing the manuscript. We also thank reviewers for very helpful suggestions to improve the manuscript.

Open Access This article is distributed under the terms of the Creative Commons Attribution 4.0 International License (http://creativecommons.org/licenses/by/4.0/), which permits unrestricted use, distribution, and reproduction in any medium, provided you give appropriate credit to the original author(s) and the source, provide a link to the Creative Commons license, and indicate if changes were made.

\section{References}

Alexander LV, Zhang X, Peterson TC et al. (2006) Global observed changes in daily climate extremes of temperature and precipitation. J Geophys Res 111:1984-2012. doi:10.1029/2005JD006290

Ariuntsetseg L, Boldgiv B et al. (2013) Effects of grazing on plant community structure and above ground net primary production of semi-arid boreal steppe of northern Mongolia. Grassl Sci 59:135-145. doi:10.1111/ grs. 12022

Barfield TJ (1989) The perilous frontier. Nomadic empires and China 221 BC to AD 1757. Blackwell Publ, Cambridge

Bates B, Kundzewicz ZW, Wu S, Palutikof JP, Eds (2008) Climate change and water. Technical Paper of the Intergovernmental Panel on Climate Change, IPCC Secretariat, Geneva, 210 pp doi:http://ipcc.ch/pdf/ technical-papers/climate-change-water-en.pdf

Batjargal Z (2007) Fragile environment, vulnerable people and sensitive society. Kaihatu-Sha Co., Ltd., Japan

Berg P, Moseley C, Haerter JO (2013) Strong increase in convective precipitation in response to higher temperatures. Nat Geosci 6:181-185. doi:10.1038/ngeo1731

Berkes F (2008) Sacred ecology, 2nd edn. Routledge, NY, 313 pp

Crate SA (2008) Gone the Bull of Winter? Grappling with the cultural implications of and anthropology's role(s) in global climate change. Curr Anthropol 49:569-595

Crate SA (2011a) A political ecology of "Water in Mind": Attributing perceptions in the era of global climate change. Weather, Climate, Soc 3:148-164

Crate SA (2011b) Climate and culture: anthropology in the era of contemporary climate change. Annu Rev Anthropol 40:175-194

Crate SA (2012) Climate change and ice dependent communities: perspectives from Siberia and Labrador. Polar J 2:61-75 
Cuerrier A, Brunet ND et al. (2015) The study of Inuit knowledge of climate change in Nunavik, Quebec: a mixed methods approach. Hum Ecol. doi:10.1007/s10745-015-9750-4

(Published online first)

Dagvadorj D, Natsagdorj L, Dorjpurev J, Namkhainyam B (2009) Mongolia assessment report on climate change 2009. Ministry of Nature, Environment and Tourism, Ulaanbaatar

Dore MHI (2005) Climate change and changes in global precipitation patterns: what do we know? Environ Int 31:1167-1181. doi:10.1016/j.envint.2005.03.004

Easterling DR, Evans JL, Groisman PYa et al. (2000) Observed variability and trends in extreme climate events: a brief review. Bull Am Meteorol Soc 81:417-425. doi:10.1175/1520-0477(2000)081<0417:OVATIE >2.3. $\mathrm{CO} ; 2$

Feng Q, Guo X, Zhao W et al. (2015) A comparative analysis of runoff and soil loss characteristics between "extreme precipitation year" and "normal precipitation year" at the plot scale: a case study in the loess plateau in China. Water 7:3343-3366

Fernandez-Gimenez M (1993) The role of ecological perception in indigenous resource management: a case study from the Mongolian forest-steppe. Nomadic Peoples 33:31-46

Fernandez-Gimenez M (2000) The role of Mongolian nomadic pastoralists' ecological knowledge in rangeland management. Ecol Appl 10:1318-1326. doi:10.1890/1051-0761(2000)010[1318:TROMNP]2.0.CO;2

Fernandez-Gimenez M, Batjav B, Baival B (2012) Lessons from the dzud: adaptation and resilience in Mongolian pastoral socio-ecological systems. World Bank, Washington DC

Glickman TS, Frey M, Hendl RG, Podsiadlo (2000) Glossary of meteorology, 2nd edn. American Meteorological Society, Boston

Groisman PY, Knight RW, Easterling DR et al. (2005) Trends in intense precipitation in the climate record. J Clim 18:1326-1350. doi:10.1175/JCLI3339.1

Haerter JO, Berg P (2009) Unexpected rise in extreme precipitation caused by a shift in rain type? Nat Geosci 2: 372-373. doi:10.1038/ngeo523

Heisler-White JL, Knapp AK, Kelly EF (2008) Increasing precipitation event size increases aboveground net primary productivity in a semi-arid grassland. Oecologia 158:129-140. doi:10.1007/s00442-008-1116-9

Humphrey C, Sneath D (1999) The end of nomadism? Society, State and the environment in Inner Asia. Duke Univ, Press

IPCC (2007) Climate change 2007: Impacts, adaptation and vulnerability, contribution of working group II to the fourth assessment report of the intergovernmental panel on climate change. In: Parry ML, Canziani OF, Palutikof JP, van der Linden PJ, Hanson CE (eds). Cambridge University Press, Cambridge, pp 976

IPCC (2012) Managing the risks of extreme events and disasters to advance climate change adaptation. In: Field CB, Barros V, Stocker TF, Qin D, Dokken DJ, Ebi KL, Mastrandrea MD, Mach KJ, Plattner GK, Allen SK, Tignor M, Midgley PM (eds) A special report of working groups I and II of the Intergovernmental Panel on Climate change. Cambridge University Press, Cambridge,

582 pp

Jigjsuren O, Baival B, Nayanaa K, Jargalsaikhan A, Dash K, Badamkhand B, Bud A (2015) Evaluating the impact of climate change based on herders' observations and comparing it with hydro-climatic and remote sensing data. Proceedings of the Trans-disciplinary Research Conference: Building Resilience of Mongolian Rangelands, Ulaanbaatar Mongolia, pp. 235-242

Jones RH, Westra S, Sharma A (2010) Observed relationships between extreme sub-daily precipitation, surface temperature, and relative humidity. Geophys Res Lett 37:1-11. doi:10.1029/2010GL045081

Knapp AK, Beier C, Briske DD et al. (2008) Consequences of more extreme precipitation regimes for terrestrial ecosystems. BioScience 58:1-11. doi:10.1641/B580908

Kozhova OM, Shagdarsuren O, Dashdorj A, Sodnom N (1989) Atlas of Lake Hövsgöl. USSR, Moscow

Lehmann J, Coumou D, Frieler K (2015) Increased record-breaking precipitation events under global warming. Clim Chang 2015:1434. doi:10.1007/s10584-015-1434-y

Lenderink G, van Meijgaard E (2008) Increase in hourly precipitation extremes beyond expectations from temperature changes. Nat Geosci 1:511-514. doi:10.1038/ngeo262

Lenderink G, van Meijgaard E (2010) Linking increases in hourly precipitation extremes to atmospheric temperature and moisture changes. Environ Res Lett 5:1-9. doi:10.1088/1748-9326/5/2/025208

Lesk C, Rowhani P, Ramankutty N (2016) Influence of extreme weather disasters on global production. Nature 529:84-88

Mallakpour I, Villarini G (2015) The changing nature of flooding across the central United States. Nat Clim Chang 5:250-254. doi:10.1038/nclimate2516

Marin A (2010) Riders under storms: contributions of nomadic herders' observations to analysing climate change in Mongolia. Glob Environ Chang 20:162-176. doi:10.1016/j.gloenvcha.2009.10.004

Mooney H, Larigauderie A, Cesario M et al. (2009) Biodiversity, climate change, and ecosystem services. Curr Opin Environ Sustain 1:46-54. doi:10.1016/j.cosust.2009.07.006 
Moseley C, Berg P, Haeter JO (2013) Probing the precipitation life cycle by iterative rain cell tracking. J Geophys Res Atmos 118:13361-13370

NAMHEM (2008) Manual for issuing hazardous weather, hydrologic, and natural phenomena (in Mongolian). National Agency of Meteorology, Hydrology, and Environment Monitoring), $4^{\text {th }}$ Edn., Ulaanbaatar, Mongolia

Nandintsetseg B, Shinoda M (2013a) Assessment of drought frequency, duration, and severity and its impact on pasture production in Mongolia. Nat Hazards 66:995-1008. doi:10.1007/s11069-012-0527-4

Nandintsetseg B, Shinoda M (2013b) Multidecadal changes in soil and vegetation in the Mongolian temperate grasslands. International Workshop on Terrestrial Change in Mongolia. JAMSTEC, Tokyo Japan 2:22-23

Nandintsetseg B, Shinoda M (2014) Multi-decadal soil moisture trends in Mongolia and their relationships to precipitation and evapotranspiration. Arid Land Res Manag 28:247-260. doi:10.1080/15324982.2013. 861882

Nandintsetseg B, Greene JS, Goulden CE (2007) Trends in extreme daily precipitation and temperature near Lake Hövsgöl, Mongolia. Int J Climatol 27:341-347. doi:10.1002/joc.1404

Parlee B, Manseau M, Ke L Dene First Nation (2005) Using traditional knowledge to adapt to ecological change: Denesqline monitoring of caribou movements. Arctic 58:26-37

Parlee B, Berkes F, Gwich'in T (2006) Indigenous knowledge of ecological variability and commons management: a case study on berry harvesting from northern Canada. Hum Ecol 34:515-528. doi:10.1007/s10745006-9038-9

Rahmani V, Hutchinson S, Harrington JA Jr (2015) Analysis of frequency and magnitude of extreme rainfall events with potential impacts on flooding: a case study from the central United States. Int J Climatol. doi:10. $1002 /$ joc. 4577

Rulfova Z, Kysely J (2013) Disaggregating convective and stratiform precipitation from station weather data. Atmos Res 134:100-105. doi:10.1016/j.atmosres.2013.07.015

Rulfova Z, Kysely J (2014) Trends of convective and stratiform precipitation in the Czech Republic, 1982-2010. Adv Meteorol 2014:1-11. doi:10.1155/2014/647938

Sala OE, Lauenroth WK (1982) Small rainfall events: an ecological role in semiarid regions. Oecologia 53:301304

Simelton E, Quinn CH, Batisani N et al. (2013) Is rainfall really changing? Farmers' perceptions, meteorological data, and policy implications. Clim Dev 5:123-138. doi:10.1080/17565529.2012.751893

Spence LA, Liancourt P, Boldgiv B et al. (2015) Short-term manipulation of precipitation in Mongolian steppe shows vegetation influenced more by timing than amount of rainfall. J Veg Sci. doi:10.1111/jvs.12349

Sun B, Groisman PY (2000) Cloudiness variations over the former Soviet Union. Int J Climatol 20:1097-1111, 10.1002/1097-0088(200008)20:10<1097::AID-JOC541>3.0.CO;2-5

Thomey ML, Collins SL, Vargas R et al. (2011) Effect of precipitation variability on net primary production and soil respiration in a Chihuahuan Desert grassland. Glob Chang Biol 17:1505-1515. doi:10.1111/j.13652486.2010.02363.x

Trenberth KE, Dai A, Rasmussen RM, Parsons DB et al. (2003) The changing character of precipitation. Bull Am Meteorol Soc 84:1205-1217. doi:10.1175/BAMS-84-9-1205

Westra S, Alexander LV, Zwiers FW (2013) Global increasing trends in annual maximum daily precipitation. J Clim 26:3904-3918. doi:10.1175/JCLI-D-12-00502.1

Westra S, Fowler HJ, Evans JP et al. (2014) Future changes to the intensity and frequency of short-duration extreme rainfall. Rev Geophys 52:522-555. doi:10.1002/2014RG000464 